\title{
The waiting room: potential for people with arterial hypertension to learn
}

\author{
Sala de espera: potencial para a aprendizagem de pessoas com hipertensão arterial \\ Sala de espera: potencial para el aprendizaje de personas con hipertensión arterial
}

\section{Maria de Lourdes Barbosa Negrão', Patrícia Costa dos Santos da Silva", Camila Maria Silva Paraizo', Roberta Garcia Gomes', Eliza Maria Rezende Dázio', Eliane Garcia Rezende', Zélia Marilda Rodrigues Resck', Silvana Maria Coelho Leite Fava'}

' Universidade Federal de Alfenas, School of Nursing. Alfenas, Minas Gerais, Brazil. "Universidade Federal de Uberlândia, School of Medicine. Uberlândia, Minas Gerais, Brazil.

How to cite this article:

Negrão MLB, Silva PCS, Paraizo CMS, Gomes RG, Dázio EMR, Rezende EG, et al. The waiting room: potential for people with arterial hypertension to learn. Rev Bras Enferm [Internet]. 2018;71(6):2930-7.

DOI: http://dx.doi.org/10.1590/0034-7167-2017-0696

Submission: 10-03-2017_Approval: 03-21-2018

ABSTRACT

Objective: To analyze the meanings assigned by people with systemic arterial hypertension to health education actions in the waiting room. Method: This is an analytical qualitative study, held in 2016 with 19 people with arterial hypertension from a health unit. The data were collected in households, through a semi-structured interview and field notes, recorded on audio, transcribed and organized by thematic analysis, being analyzed considering Vygostky's Cultural-Historical Learning Theory. Result: Meanings of attention, interest, pleasure and learning assigned to educational practice denote the importance of interaction and mediation to reconstruct knowledge about blood pressure control and to attribute a new meaning to self-care. Final considerations: The waiting room became an environment that promoted interaction, favoring the construction of meanings and internalization of knowledge with potential for lifestyle changes. Descriptors: Hypertension; Health Education; Primary Health Care; Nursing Care; Promotion of Health.

\section{RESUMO}

Objetivo: Analisar os significados atribuídos pelas pessoas com hipertensão arterial sistêmica às ações de educação em saúde em sala de espera. Método: Estudo qualitativo, analítico, realizado em 2016, com 19 pessoas com Hipertensão Arterial de unidade de saúde. Dados coletados no domicílio em entrevista semiestruturada e diário de campo, gravados em áudio, transcritos e organizados pela análise temática e analisados à luz da Teoria de Aprendizagem Histórico-Cultural de Vygotsky. Resultado: Os significados atribuídos à prática educativa de atenção, interesse, prazer e aprendizado, denotam a relevância da interação e da mediação compartilhada para a reconstrução de conhecimentos para o controle da pressão arterial e a ressignificação do cuidado de si. Considerações finais: A sala de espera configurou um espaço promotor de interação que favoreceu a construção de significados, de atenção, de interesse, de orientação, de aprendizado e de prazer, a internalização de conhecimentos com potencial para mudanças de estilo de vida.

Descritores: Hipertensão; Educação em Saúde; Atenção Primária à Saúde; Cuidados de Enfermagem; Promoção da Saúde.

\section{RESUMEN}

Objetivo: Analizar los significados atribuidos por personas con hipertensión arterial sistémica a las acciones de educación en salud en sala de espera. Método: Estudio cualitativo, analítico, realizado en 2016 con diecinueve personas con hipertensión arterial de una unidad de salud. Los datos fueron recolectados en las residencias, en entrevista semiestructurada y diario de campo, grabados en audio, transcritos y organizados por el análisis temático, siendo analizados a la luz de la Teoría de Aprendizaje HistóricoCultural de Vygotsky. Resultado: Los significados de atención, interés, placer y aprendizaje atribuidos a la práctica educativa denotan la relevancia de la interacción y mediación para reconstruir conocimientos dirigidos al control de la presión arterial y para resignificar el cuidado de sí. Consideraciones finales: La sala de espera configuró un espacio promotor de la interacción, favoreciendo la construcción de significados y la internalización de conocimientos con potencial para cambios de estilo de vida. Descriptores: Hipertensión; Educación en Salud; Atención Primaria de Salud; Atención de Enfermería; Promoción de la Salud. 


\section{INTRODUCTION}

The waiting room is a dynamic environment, which mobilizes people waiting for their consultation and who find opportunities to have conversations, share experiences with each other, observe, feel touched and express themselves through an interactive communication process ${ }^{(1-2)}$.

Using this environment to promote care methodologies can help to minimize the feelings of anxiety, fear, sadness and anguish and, concomitantly, promote health education ${ }^{(2-3)}$. Studies ${ }^{(2,47)}$ have shown that the waiting room has been valued by health professionals to promote the exchange of knowledge and group experiences.

This study prioritized educational actions involving people with systemic arterial hypertension due to the high incidence rates of this disease, which affects $32 \%$ of adults and $60 \%$ of older adults ${ }^{(8)}$, in addition to having a multifactorial nature ${ }^{(9)}$ and being a disease manageable through lifestyle changes ${ }^{(10-11)}$.

Because it is a manageable condition, people with hypertension are required to change habits, which is an essential step for adherence to treatment. However, the literature has supported that people with hypertension present difficulties in adhering to the treatment ${ }^{(12)}$, considering that it is a multifactorial process, that starts from the recognition, acceptance and adaptation to such health condition, as well as the identification of risk factors and development of self-care seeking to improve the lifestyle ${ }^{(13)}$. Developing multidisciplinary teamwork becomes fundamental, especially in primary health care through education actions that allow arterial hypertension patients to be more proactive and have autonomy over their own treatment ${ }^{(11)}$. In this sense, health education actions must provide the possibility of exchange, valuing the singularities in the process of getting sick to allow the participation of all - health professionals and people who seek care - in the construction of actions, as well as recognizing that learning occurs by interacting with the other. Considering these assumptions, health actions must be built with and not for the hypertension patient, which is in line with the concepts of Vygostky's theory of historical-cultural learning ${ }^{(14)}$ by understanding that humans are historical and cultural beings, who learn, construct new meanings and develop themselves by interacting with the other.

Applying these concepts to health education, especially considering people with chronic conditions, we recognize that the interaction mediated by language allows subjects to construct their own system of signs, which are represented in this study by the interpretation, appropriation and internalization of health guidelines that are manifested by how people perform self-care and by behavior changes ${ }^{(14)}$.

In this understanding, since 2015, once a week, in the morning, a project called "Healthy chat in the waiting room" (BatePapo saudável em sala de espera) has occurred, especially for people with hypertension seeking health care in the unit. The project was based on the strategic planning built collectively by health workers and people serviced in the Family Health Strategy Unit (UESF - Unidade Estratégia Saúde da Família), under the guidance of a university researcher. Arterial hypertension was the object of this planning, given the high rates of this disease in the population of the unit and the resulting complications.
The appointment schedule was changed to contemplate most people with arterial hypertension. The collectively constructed actions guided themes related to the promotion of health: healthy eating, anti-smoking actions, better coexistence with systemic arterial hypertension, breast self-examination and preventive examination, healthy eating and diabetes mellitus, physical activity in arterial hypertension control. The themes were developed through active methodologies, such as conversations, building a food pyramid from collages, and recognition of a healthy or unhealthy female reproduction system by using mannequins. This proposal sought to create an environment for the exchange of experiences, opportunities for participation, discussion and questions, aiming to democratize the horizontality of relationships and knowledge, allowing the seek for improvements in lifestyle and attributing new meanings to health care.

From these considerations, we must ask: what meanings are assigned by people with systemic arterial hypertension to health education actions developed in the waiting room of a UESF? This study was developed to answer this concern.

\section{OBJECTIVE}

To analyze the meanings assigned by people with systemic arterial hypertension to health education activities in the waiting room.

\section{METHOD}

\section{Ethical aspects}

This study is part of a larger research project, named "Strategic Planning and the role of the UESF staff in the promotion of health of people with Systemic Arterial Hypertension (Planejamento estratégico e o papel da equipe da UESF na promoção da saúde de pessoas com HAS)" and was approved by the Research Ethics Committee of the Universidade Federal de Alfenas. Ethical principles such as signing the informed consent form and secrecy were respected. Participants had their identity preserved through the use of fictitious names.

\section{Type of study}

This is an analytical qualitative study, based on data that cannot be quantified because they refer to meanings, values, aspirations and beliefs ${ }^{(15)}$.

\section{Study scenario}

This research was conducted in a UESF in the state of Minas Gerais, Brazil, which assists a population of 2,599 people, among which 512 are hypertension patients.

The waiting room of the UESF consists of an environment near the reception, and has enough chairs to accommodate 15 people. Although the work process foresees a scheduled program, the patients arrive early, on the start of the workday of the unit. The secretary meets the patients and fills their record, referring them to the screening room for measuring blood pressure and weight. After this process, they return to the waiting room for the consultation with health professionals. The average wait time is 30 minutes. 


\section{Data source}

Study participants were selected by convenience, and the social group was composed of nineteen people who met the following inclusion criteria: being at least 18 years old, being diagnosed with systemic arterial hypertension, being registered in the UESF, having a medical chart and having participated in at least two health education activities conducted in the waiting room.

\section{Data collection and organization}

For data collection, questions to perform the participants' demographic characterization and learn the meanings people hypertension assign to the actions of health education conducted in the waiting room were used. The approach comprised the following questions: what was it like for you to have participated in the educational activities? How did you feel? Do you remember the guidelines about high blood pressure?

Data collection was performed at home by the researcher after previously scheduling an appointment, from September, 2015 to February, 2016. The researcher did not know the participants. The semi-structured interview format was used, being recorded using a digital recorder and field notes. On average, two interviews per participant were performed, being immediately transcribed in the text editor Microsoft Word 2010. Two researchers listened to the interviews after editing. The organization of data considered the three phases of thematic content analysis ${ }^{(16)}$. A pre-analysis was conducted by reading the transcriptions, which allowed the researchers to highlight words and phrases that made sense considering the concepts of Vygostky's theory of historical-cultural learning ${ }^{(14)}$. The transcriptions were separated by identifying registration units. Following, these units were grouped according to their similarity, being encoded and named considering the concepts of the theory of historical-cultural learning, which constituted the sub-themes. The sub-themes were read, analyzed and grouped, originating the following themes: "The interaction in the waiting room: an environment to attribute new meanings"; "Mediated relationship: the use of language and instruments"; and "Learning: the potential of health education actions in the waiting room".

\section{RESUITS}

The results found that most participants were women (73\%), aged between 40 and 80 years, with mean 62 years of age. Regarding schooling, $74 \%$ had incomplete middle education. With regard to marital status, married patients represented $42 \%$ of the sample, followed by singles (26\%). The self-reported household income was between one and three minimum wages (94\%), considering a minimum wage of 788.00 reais per month in Brazil. Regarding religious beliefs, $84 \%$ of participants declared to be Catholic. The mean time of arterial hypertension diagnosis were nine years, with prevalence of exclusive pharmacological treatment $(84 \%)$, followed by non-pharmacological and dietetic treatments $(16 \%)$. This data is relevant because it shows that the health education actions developed in the waiting room that prioritize lifestyle changes are relevant, considering that such behavior changes has not yet shown to be significant and internalized by arterial hypertension patients.
Data analysis considering Vygostky's theory of historicalcultural learning, using the concepts of interaction, mediation and learning, allowed the construction of three themes, which will be presented below ${ }^{(14)}$.

\section{The interaction in the waiting room: an environment to} attribute new meanings

Interactions are fundamental for humans to have relationships, learn and reach the development stages that allow them to become capable of performing actions without help from others. The following quotation exemplifies the importance of interactions:

I felt that it was a lot of attention, something that never happened elsewhere... usually the doctors come in and don't look at anyone, they simply come in and discharge the patients in a minute, and he was attentive when I came in for the consultation, he asked a lot of questions and took his time. This is important, when we feel that he's not in a hurry, that he talked to us, that he's with us, especially because it was my first consultation with him, it was the doctor... that was the first time he went, he asked a lot of questions about my family, he wanted to know everything. The doctor is new now, then he came and held a meeting with everyone, he talked about hypertension... he gave a lecture, I enjoyed it, he was very attentive. (Laura)

The fact that health care workers are concerned with changing the schedule of consultations to organize the meetings according to specific gender needs facilitated the reception, conversations, and exchange of knowledge, enabling interactions and corroborating to the construction of meanings.

I enjoyed it and there were only women at the reception, they made sure to only call women to have consultations this day, precisely to make this lecture [preventive and breast examinations]. (Alice)

Although waiting for a medical consultation is loaded with emotional experiences, feelings of anxiety, irritation and sadness due to the delay in the appointment or by the expectation of a diagnosis (as recorded in field notes), the participation in the chat in the waiting room functioned as a safety valve, minimizing these feelings, as can be seen in the following quotation:

We were more relaxed, because we always get anxious waiting, and everyone's like this. But not on that day, the nurse kept talking and talking, the time passed and a moment later, I was in my appointment, it was very fast. (Ana)

Mediated relationship: the use of language and instruments

The following quotations express the relevance of mediation through the symbolic system, represented by language and teaching resources that people used to conceive their relationship with the world:

[They] showed a written poster, provided examples, exemplified, spoke in a language of the people, because there are people who have a hard time understanding... it needs to be spoken in a comprehensible language, simpler, for the person to understand. I thought it was good, I liked it... (Sandra) 
This last time I went, the nurse talked a lot about the breast cancer. She placed a breast and an uterus on the coffee table, everything was organized and she explained what is cancer, how it begins, so we can check the nodules at home, the things, she explained how are the nodules and explained everything. (Ana)

The following quotation reiterates the perception of participants about having room for dialogue and about feeling as participants in actions:

We participated picking a food, I remember this and there's probably more things, but we also did not expect it because I chose that food that we thought would be better, I even picked watermelon, which is a food that is good for pressure after the meal, we had a piece of paper that we filled. Below is what we eat first, so I chose watermelon, which is after the meal, then the others chose something, a candy a little higher. (Rosa)

\section{Learning: the potential of health education actions in the} waiting room

Considering Vygostky's theory of historical-cultural learning ${ }^{(14)}$, the learning process is developed in relationships with the Other and is mediated by signs. In this study, the Other refers to health care professionals from the UESF staff and the people with arterial hypertension who waited in the waiting room. In this understanding, the signs were represented by the language, as well as mannequins, collages to construct a food pyramid and images.

People used the language to interact, learn and improve their representations about the world. The following quotations exemplify the learning:

Due to knowing more, we start doing it on ourselves, especially during bath, the nurse explained that it is like this [at this moment, Ana felt her own breast, showing how she should do it when bathing] so we start doing it to see it, it is always nice to have someone guiding us, we're foolish and don't know very much. We learned more things we did not know, we learned with her. (Ana)

He said we must be careful with our feeding, exercise, he said: hey everyone, salt is the greatest enemy, he was commenting about salt you know, then he talked to everybody: you have to go hiking, because hiking is very important. (Laura)

\section{DISCUSSION}

The demographic characterization of participants is similar to those found in other studies of people with systemic arterial hypertension ${ }^{(17)}$. Schooling reflects the need to facilitate the access to educational activities and the exchange of knowledge, increasing the participation and expression of health care ${ }^{(18)}$.

To learn and develop themselves, human beings create interaction and mediation mechanisms to have relationships with the world, and the language has a key role in this process. Through language, humans construct meanings and assign senses to things and the world ${ }^{(19)}$. The meaning is a constitutive and essential trait of a word, i.e., is the very word seen in its interior aspect ${ }^{(14)}$.

\section{The interaction in the waiting room: an environment to} attribute new meanings

Regarding the first theme, we found that the meanings assigned by the social group to the health education actions developed in the waiting room enabled the creation of an interaction environment that favored the attention, interest, guidance, learning and pleasure, as reported by the study participants.

Therefore, the participants felt valued and respected because the health workers dedicated their time, by being attentive and listening, which points to the importance of the Other in the appropriation of meaning. The sensitivity, affection and emotion that permeated these interactions favored the construction of meanings by the participants. In health education actions, health professionals must be attentive and look in people's eyes; use simpler language, demonstrating interest and empathy motivational elements of group participation that allow dialogic interactions for the sharing of knowledge ${ }^{(4,20)}$.

Health education groups represent one of the main means for the construction of knowledge on a given subject, due to facilitating the exchange of scientific and popular knowledge, as these provide a dialogical relationship and the valuation of singularities ${ }^{(21-23)}$.

The reality experienced by study participants is not very common in the daily life of health care, because culturally, there is still a lack of professionals who provide attention and create possibilities to facilitate the interaction, thus decreasing the distance between the staff and the patient. We found that the attention of professionals brought changes in the consultation, especially to Laura, who felt welcome and with space for dialogue; we can presume that this interaction favored the expression of her needs.

The reception is fundamental in people's accessibility to health services, being one of the main forms of humanization and health care $^{(24)}$. Offering an appropriate reception, listening to the population who seeks the service, meeting their needs and the completeness of care, are crucial items in this process ${ }^{(2,25)}$ and one of the ways to overcome the limits of the traditional health care model ${ }^{(26)}$.

The waiting room space has shown its potential, because the interaction between the participants and the health professionals allowed the creation of an environment of pleasure. The meetings were a constructive, pleasurable and meaningful time, which favored bonding and during which people felt active. The waiting room was a living and humanized space, permeated by affection and emotionality, allowing the construction of meanings that are shared, appropriated and internalized. Thus, the meaning is constructed by people as they have conversations, listen and are heard about the difficulties of taking care of their own health.

Mediated relationship: the use of language and instruments

From the second theme, we comprehended that the interaction and coexistence with the Other enables people to build their own systems of signs, mediator elements that support individuals when they act on the world.

The written language represents a sign and is considered the most important symbolic system that human beings have to form concepts, interact and learn ${ }^{(17)}$. The instrument is every object created by humans with the intention of facilitating their labor 
and survival. Thus, instruments are mediators between a person and their labor, being in an external plane to human beings ${ }^{(27)}$.

We found that the use of clear and objective language functioned as an important mediator that favored the understanding and approach of the participants, in addition to relieving anxiety. Thus, it allowed each participant to express their own sickness, encouraging empathy, interest, the desire for further comprehension, in addition to creating environments to strengthen ties and reflect on health care and the ability to manage their own process of getting sick. Thus, the importance of human relationships for the socialization of knowledge and formation of subjects is understood ${ }^{(28-31)}$, as explained by participants.

Although conducted over two months after the actions, the interviews show that the participants recalled, in detail, the professionals, guidelines, techniques and material resources. We can affirm that the language and instruments were critical mediation elements for the construction of knowledge, for the internalization, and possibly for the attribution of new meanings to care procedures.

In this perspective, the waiting room environment showed its potential by allowing people's needs to be met by prioritizing listening, speaking, observing, understanding, reflecting and acting, and respecting the subject's culture, so everyone felt as participants of the process.

Considering the importance of interactions for people's psychological development, which occurs from a stage that has been reached and is consolidated ${ }^{(14)}$, the following levels of development are established: the real, which corresponds to the point reached; the potential, in which the person can act with the help of others; and the zone of proximal development (ZPD), situated between both previous stages and that defines functions that are already in the process of maturation - something that must be considered in teaching and learning. From these concepts, we understand that learning is continuous and a response to experiences in the social environment ${ }^{(29)}$, and that it is produced by the constant dialogue between the exterior and interior of a human being, considering the need for exchanges with the external world for the formation of mental actions ${ }^{(14)}$.

The results of this study reiterate that the waiting room environment, mediated by signs and instruments, was able to stimulate the ZPD and promote the internalization of the guidelines. The waiting room has been a privileged space for dialogue and for the use of simple materials, exhibiting posters and images, and demonstrating procedures ${ }^{(32)}$. Such instruments have contributed to change some social practices, such as communication, socialization, organization, mobilization and learning. Studies ${ }^{(21,33-34)}$ that conducted actions through workshops, including interactive lectures and activities using different resources (such as posters, videos and practical demonstrations?), concluded that those health education strategies are important and effective to increase adherence to guidelines and counteract the traditional methodologies, which are less effective in the consolidation of knowledge ${ }^{(33)}$.

Educational actions enable people to learning and development: it is the approach of what can be done with the help of the other so the individual can do it him/herself ${ }^{(17)}$. The concepts of Vygostky's cultural-historical theory ${ }^{(14)}$ have been used in studies that reinforce the importance of mediation in the learning process ${ }^{(35-36)}$, concluding that the community itself has the potential to teach professionals; whom, in turn, are encouraged to continue conducting health care promotion actions. Therefore, this is a dialectical and cultural process. The conclusions of these authors, as well as of this study, show the importance of the social context, under the mediation of signs and instruments, to understand that the trajectory of cognitive development occurs in the social sense for individuals ${ }^{(14)}$.

\section{Learning: the potential of health education actions in the waiting room}

The importance of learning in Vygotsky's theory ${ }^{(14)}$ sets the third theme, being based on the principle that humans are historical and cultural beings, whom learn by interacting with the other, constructs new meanings and develops itself. From this assumption, learning is consolidated in the dialogical and dialectical relation, in which everyone teaches and learns, since the established relationships are are pedagogical ${ }^{(37)}$.

Considering this idea, the waiting room was an environment that allowed conversations, sharing ideas and experiences, and for this reason, the actions were construed as privileged for the construction of knowledge about health ${ }^{(21)}$. It is a space that serves health education by implying the management of knowledge in the relationship and health care procedures, and not to control the lifestyle of patients ${ }^{(2)}$.

The appropriation of knowledge for the promotion of self-care was perceived, strengthening the personal and consequently, social transformations, which helps the individual to leave his/her comfort zone; a passive subject becomes active in the teaching and learning process.

Thus, according to the theory of historical-cultural learning, the appropriation of knowledge occurs in the subject's relations with the world, enabling the internalization, and consequently, learning ${ }^{(14)}$. To Vygostky, there is not a set development that is updated over time. Development is a process in which the maturation of the organism, the contact with the culture produced by humanity and social relations are present. Therefore, internalization is an interpersonal process that is transformed into intrapersonal, since all development functions occur at two levels: first at social level, in the interaction with different people; then, at the individual level, within each subject. Therefore, all higher functions derive from the relations among people $\mathrm{e}^{(14)}$.

In this understanding, an individual cannot be seen as a mere object that needs to adapt to society's conditions. On the contrary, individuals must be recognized from the relations established with material and symbolic goods that are appropriated so he/she can develop and satisfy his/her needs, thus assuming the position of subject of in their own learning process $^{(38)}$. By analyzing the results of this study considering the proposed theoretical framework, we found that the waiting room was a favorable environment for the appropriation of cultural tools, enabling new forms of expression of thought. These considerations about health education require these actions to seek the development of the autonomy and self-care of people - not in a vertical manner through the technical and scientific knowledge held by healthcare professionals, but mainly through the development of skills to handle the daily difficulties 
imposed by the disease ${ }^{(39)}$, especially in the case of hypertension patients, whom present extremely complex demands ${ }^{(33)}$.

For such, using active methodologies, prioritizing the dialogical relationship, valuing singularities and sharing knowledge and practices, will provide to the patient the feeling of belonging to his/her knowledge-building process, with potential to learn and develop autonomy ${ }^{(30)}$. These conceptions reiterate that humans are social beings, that learn by interacting with each other and, thus have the mission to provide a favorable social environment for development. Health professionals play a vital role in the learning process when they value the waiting room as an environment for reception and dialogue ${ }^{(40)}$.

The potential of waiting rooms in the teaching and learning process was also identified in other studies ${ }^{(21,41)}$, which pointed group meetings as one of the main links for the construction of knowledge in health care due to allowing different cultures, knowledge and worldviews to be shared. In these meetings, each person is different and recognizes him/herself in the other through a dialogical relationship that allows them to talk, listen, reflect, question and learn mutually.

Health education actions conducted in the waiting room with people with systemic arterial hypertension were an effective intervention strategy, because they favored the internalization and stimulated lifestyle changes, which fills one of the gaps identified in the literature ${ }^{(10)}$.

\section{Study limitations}

This study was developed with people with systemic arterial hypertension, mostly women. We suggest studies with groups comprised of more men, and of people with other chronic conditions.

\section{Contributions to the field of Nursing}

Nursing activities are within a very wide field of action and, in spite of scientific knowledge, the demand and scope of actions under the responsibility of nurses are extensive, especially when involving people with chronic conditions whom present impairments in different dimensions. To handle this challenge, nurses must seek to develop their practice in articulation and integration with the multidisciplinary team, through active methodologies that allow the approximation, interaction and shared construction of knowledge.

The results of this study, based on Vygostky's theory of historicalcultural learning ${ }^{(14)}$, shows the potential of waiting rooms for health education actions, being understood as a living and humanized space by making the nurse and the person seeking the service be closer, enabling the expression of feelings, knowledge and the construction of knowledge for learning and autonomy. This theory, and others that are similar, must be addressed in nursing undergraduate courses during their training process.

\section{FINAL CONSIDERATIONS}

The waiting room became an environment that promoted interaction, favored the construction of meanings, interest, guidance, learning and pleasure, contributed to the internalization of knowledge with potential for lifestyle changes.

This study allowed us to understand that the person seeking care needs to take an active role in this process, because he/she interacts with the other through social experiences, and learns based on what is meaningful to him/her. Therefore, this person must be helped to find answers for his/her needs. The health professional must provide support; must give voice to participants, enabling the socialization of knowledge from individual experiences, which contributes to the reflection, learning, and development of autonomy, as well as to changes in the ways to provide care in more participatory ways.

This study brings contributions to health education actions directed at people with systemic arterial hypertension, considering that the interaction and mediation, according to Vygostky's theory of historical-cultural learning ${ }^{(14)}$, showed the potential of the waiting room for the learning, internalization, attribution of new meanings and possibly, the promotion of lifestyle changes.

\section{REFERENCES}

1. Pimentel AF, Barbosa RM, Chagas M.[Music therapy in the waiting room in a primary healthcare unit: care, autonomy and protagonism]. Interface[Internet]. 2011[cited 2018 Aug 14];15(38):741-54. Available from: http://www.scielo.br/pdf/icse/v15n38/10. pdf Portuguese.

2. Teixeira ER, Veloso RC. [The group in the waiting room: territory of practices and representations in health]. Texto Contexto Enferm[Internet]. 2006[cited 2018 Aug 14];15(2):320-5. Available from: http://www.scielo.br/pdf/tce/v15n2/a16v15n2.pdf Portuguese.

3. Frizon G, Nascimento ERP, Bertoncello KCG, Martins JJ. [Family in the waiting room of na intensive care unit: revealed feelings]. Rev Gaúcha Enferm[Internet]. 2011[cited 2018 Aug 14];32(1):72-8. Available from: http://www.scielo.br/pdf/rgenf/v32n1/a09v32n1 . pdf Portuguese.

4. Milani L, Germani ARLM. [Waiting room: a scenario for health promotion]. Rev Enferm[Internet]. 2012[cited 2018 Aug 14];8(8):11427. Available from: http://revistas.fw.uri.br/index.php/revistadeenfermagem/article/viewFile/480/874 Portuguese.

5. Nora CRD, Mânica F, Germani ARM. [Waiting room: a tool to execute the health education]. Rev Saúde Pesqui[Internet]. 2009[cited 2018 Aug 15];2(3):397-402. Available from: https://pdfs.semanticscholar.org/88b0/cb91ea5a719dd07f231b032b66ba29a582aa. pdf Portuguese.

6. Poletto PMB, Motta MG. [Education in health in the waiting room: care and actions to the child who lives with HIV/aids]. EsC Anna Nery[Internet]. 2015[cited 2018 Aug 14];19(4):641-7. Available from: http://www.scielo.br/pdf/ean/v19n4/1414-8145ean-19-04-0641.pdf Portuguese. 
The waiting room: potential for people with arterial hypertension to learn Negrão MLB, Silva PCS, Paraizo CMS, Gomes RG, Dázio EMR, Rezende EG, et al.

7. Gomes CS, Amaral JS, Dias MO, Silva PFC, Baptista ATP, Almeida IS. Sala de espera para adolescentes e familiares. Aproximando[Internet]. 2015[cited 2018 Aug 15];1(1):1-5. Available from: http://latic.uerj.br/revista/ojs/index.php/aproximando/article/view/42.

8. Sociedade Brasileira de Cardiologia. 7ª Diretriz Brasileira de Hipertensão Arterial. Arq Bras Cardiol[Internet]. 2016[cited 2018 Aug 15];107(Suppl-3):1-83. Available from: http://publicacoes.cardiol.br/2014/diretrizes/2016/05_HIPERTENSAO_ARTERIAL.pdf

9. Malta DC, Andrade SSCA, Stopa SR, Pereira CA, Szwarcwald CL, Silva Jr JB, et al. [Brazilian lifestyles: National Health Survey results, 2013]. Epidemiol Serv Saúde[Internet]. 2015[cited 2018 Aug 15];24(2):217-26. Available from: http://www.scielo.br/pdf/ ress/v24n2/2237-9622-ress-24-02-00217.pdf Portuguese.

10. Oliveira TL, Miranda LP, Fernandes PS, Caldeira AP. [Effectivenes of education in health in the non-medication treatment of arterial hypertension]. Acta Paul Enferm[Internet]. 2013[cited 2018 Aug 15];26(2):179-84. Available from: http://www.scielo.br/pdf/ape/ v26n2/v26n2a12.pdf Portuguese.

11. Secretaria de Estado da Saúde de Minas Gerais. Atenção à saúde do adulto: linha guia de HAS, diabetes mellitus e doença renal crônica. Belo Horizonte: Secretaria de Estado da Saúde de Minas Gerais; 2013.

12. Waidman MAP, Radovanovic CAT, Estevam MC, Marcon SS. [Assistance for people with hypertension in the perspective of the health professional]. Rev Bras Enferm[Internet]. 2012[cited 2018 Aug 15];65(3):445-53. Available from: http://www.scielo.br/pdf/ reben/v65n3/v65n3a08.pdf Portuguese.

13. Schmidt MI, Duncan BB, Azevedo G, Menezes AM, Monteiro CA, Barreto SM, et al. Doenças crônicas não transmissíveis no Brasil : carga e desafios atuais. Cad Ind [Internet]. 2011[cited 2018 Aug 15]:61-74. Available from: http://dms.ufpel.edu.br/ares/ handle/123456789/222

14. Vygotsky LS. A formação social da mente. São Paulo: Martins Fontes; 2007.

15. Minayo MCS. O desafio do conhecimento: pesquisa qualitativa em saúde. 12a ed. São Paulo: Hucitec; 2010.

16. Bardin L. Análise de conteúdo. Lisboa: Edições 70; 2009.

17. Brasil. Ministério da Saúde. Secretaria de Vigilância em Saúde. Departamento de Vigilância de Doenças e Agravos não Transmissíveis e Promoção da Saúde. Vigilância de fatores de risco e proteção para doenças crônicas por inquérito telefônico: estimativas sobre frequência e distribuição sociodemográfica de fatores de risco e proteção para doenças crônicas nas capitais dos 26 estados brasileiros e no Distrito Federal em 2016. Brasília: Ministério da Saúde; 2017.

18. Viegas APB, Carmo RF, Luz ZMP. [Factors associated to the access to health services from the point of view of professionals and users of basic reference unit]. Saúde Soc[Internet]. 2015[cited 2018 Aug 14];24(1):110-12. Available from: http://www.scielo.br/ pdf/sausoc/v24n1/0104-1290-sausoc-24-1-0100.pdf Portuguese.

19. Vygostsky LS. A construção do pensamento e da linguagem. São Paulo: Martins Fontes; 2001.

20. Mascarenhas NB, Melo CMM, Fagundes NC. [Production of knowledge on health promotion and nurse's practice in Primary Health Care]. Rev Bras Enferm[Internet]. 2012[cited 2018 Aug 15];65(6):991-9. Available from: http://www.scielo.br/pdf/reben/ v65n6/a16v65n6.pdf Portuguese.

21. Silva FM, Budó MLD, Girardon-Perlini NMO, Garcia RP, Sehnem GD, Silva DC. [Contribution of health education groups to the knowledge of pepople with hypertension]. Rev Bras Enferm[Internet]. 2014[cited 2018 Aug 15];67(3):347-53. Available from: http:// www.scielo.br/pdf/reben/v67n3/0034-7167-reben-67-03-0347.pdf Portuguese.

22. Pereira MDM, Pestana T, Maria E, Vaz C, Collet N. [Conceptions and practices of professional family health strategy for health education]. Texto Contexto Enferm[Internet]. 2014[cited 2018 Aug 15];23(1):167-75. Available from: http://www.scielo.br/pdf/tce/ v23n1/pt_0104-0707-tce-23-01-00167.pdf Portuguese.

23. Mendonça FF, Nunes EFPA. [ Evaluation of education in health groups for people with chronic diseases]. Trab Educ Saúde[Internet]. 2015[cited 2018 Aug 15];13(2):397-409. Available from: http:/www.scielo.br/pdf/tes/v13n2/1981-7746-tes-13-02-0397.pdf Portuguese.

24. Brehmer LCF, Verdi M. [User embracement in Basic Care: ethical implications on the Health Care of the users]. Ciênc Saúde Colet[Internet]. 2010[cited 2018 Aug 15];15(3):3569-78. Available from: http://www.scielo.br/pdf/csc/v15s3/v15s3a32.pdf Portuguese.

25. Silva LG, Alves MS. [Welcoming as a tool of inclusive health care practices]. Rev APS[Internet]. 2008[cited 2018 Aug 15];11(1):74-84. Available from: http://www.saude.sp.gov.br/resources/humanizacao/biblioteca/artigos-cientificos/artigo_-_o_acolhimento_como_ ferramenta_de_praticas_inclusivas_de_saude.pdf Portuguese.

26. Lima EFA, Sousa AI, Primo CC, Leite FMC, Lima RCD, Maciel ELN. Avaliação dos atributos da atenção primária na perspectiva das usuárias que vivenciam o cuidado. Rev Latino-Am Enfermagem[Internet]. 2015[cited 2018 Aug 15];23(3):553-9. Available from: http://www.scielo.br/pdf/rlae/2015nahead/pt_0104-1169-rlae-0496-2587.pdf

27. Goulart BNG, Chiari BM. [Thinking about health related professions humanizated practice]. Ciênc Saúde Colet[Internet]. 2010[cited 2018 Aug 15];15(1):255-68. Available from: http://www.scielo.br/pdf/csc/v15n1/a31v15n1.pdf Portuguese.

28. Oliveira MK. Vygostsky: aprendizado e desenvolvimento: um processo sócio-histórico. São Paulo: Scipione; 2010.

29. Almeida ER, Moutinho CB, Leite MTS. [Family health nurses' teaching practice in the health education development]. Interface[Internet]. 2016[cited 2018 Aug 15];20(57):389-401. Available from: http://www.scielo.br/pdf/icse/v20n57/1807-5762-icse-1807-576220150128. pdf Portuguese. 
30. Borges TS, Alencar G. Metodologias ativas na promoção da formação crítica do estudante: o uso das metodologias ativas como recurso didático na formação crítica do estudantes do ensino superior. Cairu Rev[Internet]. 2014[cited 2018 Aug 15];3(4):11943. Available from: http://www.cairu.br/revista/arquivos/artigos/2014_2/08\%20METODOLOGIAS \%20ATIVAS $\% 20$ NA $\% 20$ PROMOCAO \%20DA \%20FORMACAO \%20CRITICA\%20DO\%20ESTUDANTE.pdf

31. Dias RH. Linguagem, interação e socialização: contribuições de Mead e Bakhtin. Anais da $10^{\mathrm{a}}$ Reunião Científica da Associação Nacional de Pós-Graduação e Pesquisa em Educação[Internet]. 2014 Oct 26-29. Florianópolis: ANPED SUL; 2014 [cited 2018 Aug 15]:[18 p.]. Available from: http://xanpedsul.faed.udesc.br/arq_pdf/539-0.pdf

32. Costa SRS, Duqueviz BC, Pedroza RLS. [Digital Technologies as mediating tools of digital natives' learning]. Psicol Esc Educ[Internet]. 2015[cited 2018 Aug 15];19(3):603-10. Available from: http://www.scielo.br/pdf/pee/v19n3/2175-3539-pee-19-03-00603.pdf Portuguese.

33. Ribeiro AG, Cotta RMM, Ribeiro SMR, Dias CMGC. [Social representation of women with hypertension in relation to the disease: unraveling the adherence to the treatment in relation to the schedule of the Family Health]. Rev Saúde Colet[Internet]. 2011 [cited 2018 Aug 15];21(1):87-112. Available from: http://www.scielo.br/pdf/physis/v21n1/v21n1a05.pdf Portuguese.

34. Ribeiro AG, Cotta RMM, Silva LS, Ribeiro SMR, Dias CMGC, Mitre SM, et al. [Hypertension and educational home visits: the strategic role of family healthcare]. Rev Nutr[Internet]. 2012[cited 2018 Aug 15];25(2):271-82. Available from: http://www.scielo. br/pdf/rn/v25n2/09.pdf Portuguese.

35. Gercama A, van Lankveld T, Kleinveld J, Croiset G, Kusurkar R. Bridging the gap between CBME in theory and practice: the role of a teacher community. Perspect Med Educ[Internet]. 2014[cited 2018 Aug 15];3(6):486-91. Available from: https://www.ncbi. nlm.nih.gov/pmc/articles/PMC4263791/

36. Peck CA, Galluci C, Sloan T, Lippincott A. Organizational learning and program renewal in teacher education: a socio-cultural theory of learning, innovation and change. Educ Res Review[Internet]. 2009[cited 2018 Aug 15];4(1):16-25. Available from: http:// www.sciencedirect.com/science/article/pii/S1747938X08000249

37. Santos MMAS, Saunders C, Baião MR. [Interpersonal relations between health professional and pregnant adolescents: distances and approaches of integral and humanized care]. Ciênc Saúde Colet[Internet]. 2012[cited 2018 Aug 15];17(3):775-86. Available from: http://www.scielo.br/pdf/csc/v17n3/v17n3a25.pdf Portuguese.

38. Viotto Filho IAT, Ponce RF, Almeida SHV. As compreensões do humano para Skinner, Piaget, Vygotski e Wallon : pequena introdução às teorias e suas implicações na escola. Psicol Educ[Internet]. 2009[cited 2018 Aug 15];(29):27-55. Available from: http://pepsic. bvsalud.org/scielo.php?script = sci_arttext\&pid = S1414-69752009000200003

39. Fava SMCL, Nunes ZB, Gonçalves MFC, Nogueira MS. [Health education and treatment adherence in the historical cultural]. Saúde Transf Soc[Internet]. 2011[cited 2018 Aug 15];2(1):81-7. Available from: http://incubadora.periodicos.ufsc.br/index.php/ saudeetransformacao/article/view/1065/1289 Portuguese.

40. Tunes E. [Studies on the cultural-historical theory and its educational implications]. Fractal[Internet]. 2015[cited 2018 Aug 15];27(1):711. Available from: http://www.scielo.br/pdf/fractal/v27n1/1984-0292-fractal-27-1-0007.pdf Portuguese.

41. Rodrigues AD, Dallanora CR, Rosa J, Germani ARM. [Waiting room: an environment for effective health education]. Vivências[Internet]. 2009[cited 2018 Aug 15];5(7):101-6. Available from: http://www.reitoria.uri.br/ vivencias/Numero_007/artigos/artigos_vivencias_07/ Artigo_13.pdf Portuguese. 